\title{
GART wt Allele
}

National Cancer Institute

\section{Source}

National Cancer Institute. GART wt Allele. NCI Thesaurus. Code C128849.

Human GART wild-type allele is located in the vicinity of $21 \mathrm{q} 22.11$ and is approximately 40 $\mathrm{kb}$ in length. This allele, which encodes trifunctional purine biosynthetic protein adenosine3 , plays a role in the synthesis of purines. 